tend to be of much stiffer consistency and result in sticking of the material to the inside of the mixer. 'The efficiency of the tilting, non-tilting and other types of concrete mixer have been investigated recently at the Road Research Laboratory by a sampling procedure, and it has been shown how the mixer can be modified so as greatly to reduce this difficulty.

Dr. R. S. Millard gave an account of the difficulties involved in sampling bituminous mixes used for road construction. A special sectionalized frame has been made for taking samples from a mixer, and it has been shown that quite large variations in bitumen content are to be expected from some types of mixer which are in use at present.

The last paper, by Mr. K. A. Lammiman (Research Council, British Whiting Federation), was on "The Mixing of Linseed Oil Putty". A description was given of the present methods of making putty on a commercial scale, and of the difficulties of measuring oil absorptions for different samples of whiting. The extension before break is an important attribute of the mixed putty, and an extensometer has been constructed to measure this property more accurately than the operative's method of stretching between the hands. Considerable work has been done on the measurement of the density of the material under different conditions of mixing.

The symposium showed that industry is at least aware of the need for attacking mixing problems on a scientific basis. Further progress is to be expected when the methods described by Mr. Danckwerts are applied to the many practical mixing problems described by the other speakers. N. Wooker

\section{RESEARCH STATION OF THE PARSONS AND MARINE ENGINEERING TURBINE RESEARCH AND DEVELOPMENT ASSOCIATION}

\footnotetext{
A $\mathrm{T}$ the open day of the Research Station of the A Parsons and Marine Engineering rurbine Research and Development Association (Pametrada), held on October 5, it was noteworthy that the three and a half years which have elapsed since the Station was last open for viewing have marked a period of considerable expansion as well as the consolidation to be expected after the rapid growth of its first five years. The period also covers the running for rather more than a thousand hours of the $3,500 \mathrm{~s}$.h.p. marine gas-turbine, which was first set in motion in April 1950. The chairman of the Association, Sir Philip Johnson, pointed out in his welcoming address that this installation is a realistic one, small enough, cheap enough and efficient enough to compete economically with other forms of ship propulsion, and with a sufficient life and reliability to bo acceptable for marine service. This is not to say, of course, that there have been none of the teething troubles from which is acquired that valuable experience or 'know how'; but the lines of further development are clear ahead to the extent that the Association is now, in conjunction as usual with its member firms, in a position to produce designs for ships' gas-turbine sets which will be capable of providing the sole propulsion machinery on a satisfactory basis of economy and reliability.
}

The natural attention attracted by this large, impressive and advanced piece of development tended to overshadow the important and interesting exhibits in other parts of the laboratories, almost all of which were on show to the visitor. Work continues on research and development in connexion with steam turbines: there was on show a six-stage impulse machine known as 'Pamela', designed to provide experience with steam at high temperature and high pressure simultaneously, the maximum conditions being $1,100 \mathrm{lb}$. $/$ in. $^{2}$ and $1,100^{\circ} \mathrm{F}$. (about $600^{\circ}$ C.), and there continue to be full-scale trials run on propulsion machinery as a whole, including the turbines and their associated reduction gearing.

A considerable amount of work is going on in connexion with the development of marine reduction gearing and on long-term research into gearing problems. No less than three back-to-back rigs are employed for full-scale work on marine gear units, and in this connexion the Association has developed an ingenious hydraulic device which can be used as a torque loader and torque meter. One of the most interesting exhibits in the gearing section was that which illustrated the effect of helix correction on the life of marine turbine gearing. As is well known, marine turbine pinions have a large length/diameter ratio, and the deflexions on them due to bending, shear and torque are, in sum, considerable. By suitable adjustment of the lead of the two pinion helices with respect to those of the mating wheel, the unit can be made to transmit full load with even loading across the full face-width after taking into account the full deflexions.

Rigs for studying journal bearings, turbine blade vibrations, etc., were also to be seen in the main laboratories. It is particularly noteworthy that the work on bearings has led to the clear establishment of an optimum length/diameter ratio between $1 / 3$ and $2 / 3$. In the small-scale mechanical laboratory were three disk machines of the Amsler, Niemann and Timken types for investigations into gear materials and into problems of gear tooth lubrication, while in the applied science laboratories could be seen further long-term researches into these subjects.

The development work on combustion of fuels for gas turbines and the associated problems of fouling and corrosion were displayed in a series of interesting exhibits in the combustion laboratory. It appears that very considerable progress has been made towards solving the problems of combustion of low-grade fuels in marine gas-turbine installations.

Also as part of the combustion work a considerable number of investigations has been made into problems of oil-fuel spraying. It is particularly interesting to see the relatively large scale of the oil-fuel sprayers developed for the gas-turbine installations as com. pared with the familiar type for compression-ignition engines. The importance in the latter of equal fuel delivered to each cylinder is also paralleled by the need to ensure that multiple combustion chambers give substantially equal outputs per chamber if there are not to be wide variations of inlet temperature around the turbine. Here two developments are continuing in parallel, by improving the sprayers themselves and by the experimental use of a mixing chamber between the flame tubes and the turbine proper. Furthermore, the importance of being able to effect easy replacement of injectors in the com- 
bustion-ignition engine to maintain it in efficient service is again paralleled by the development of replaceable sprayers, which, however, have to solve the more difficult problem of replacement without shutting down the main plant.

In the aerodynamics laboratory was an interesting single-stage air turbine. The laboratory already has substantial facilities for aerodynamic work, particularly on turbine blading; but these are to be extended still further when the high-speed variable-density cascade tunnel, which has been designed to enable independent control of the Mach and Reynolds numbers, is installed.

A considerable amount of development in measurement of noise was evidenced by the equipment on view both in the applied science and in the small mechanical laboratories. Those who have experienced the unpleasant sensations which can be associated with the noise from a blower will be grateful for the development of acoustic filters which, although simple in design, were shown to reduce an almost intolerable noise to within the limits of comparative comfort.

The work at the Research Station has led to the development of a very considerable amount of ingenious and effective measuring equipment. Particular reference should perhaps be made to the wave analyser which is now being marketed commercially in the name of 'Muirhead-Pametrada'. The progress in dealing with the problem of noise and vibrations generally is striking.

The strides that have been made by the Association in the eight years since its foundation reflect immense credit on it and its staff, particularly the research director, Dr. T. W. F. Brown. One of the most important factors contributing to its achievement must undoubtedly be that the Station is closely associated with the commercial success of its designs, so that although the work is frequently of a fundamental nature or indeed concerned with the development of equipment to measure the variables in a fundamental investigation, there is in the last event the acid test of whether the designs will work in a ship's installation to keep the feet of the staff firmly on the ground. During the six years since the first turbine designed at the Station went into service, more than fifty sets have been installed and are in satisfactory operation.

\section{GEORGE E. DAVIS (1850-1907) AND CHEMICAL ENGINEERING}

A MEETING was held in Manchester on October A 10, under the auspices of the Institution of Chemical Engineers and the Society of Chemical Industry, to commemorate George E. Davis, who is recognized throughout the English-speaking world as the pioneer of chemical engineering. The principal feature of the meeting was a Memorial Lecture given at the College of Technology by Mr. Norman Swindin, who was closely associated with Davis during $1900-7$.

George Edward Davis was born at Eton in 1850 and studied chemistry at the Slough Mechanics Institute and the Royal School of Mines, London. After a period spent in obtaining industrial experience in a variety of chemical works, Davis set up in private practice, as what would now be called a consulting chemical engineer, in Manchester in 1880. Very soon after this, however, he became an alkali inspector and did not return to his private practice until 1884 . The remaining twenty-three years of his life he devoted mainly to his practice and to editing The Chemical Trade Journal, which he founded in 1887 and which still flourishes.

Davis made major contributions to two important industrial processes. His first love was the gas industry, and when he was only eighteen he began research on the extraction of benzene from coal gas ; this side of his work culminated in the erection of a by-product plant at Rockingham which was technically ahead of its time and was not superseded until after his death. He also made great contributions to the Leblanc soda process and the allied Weldon process for the manufacture of chlorine. He himself devised a process for the production of chlorine by the oxidation of hydrochloric acid by nitric acid; this was not a commercial success, largely for the same reasons, technical and economic, which were leading at this time to the rapid decline of the once all-important Leblanc process. In all his work, doubtless owing to his experience as an alkali inspector, Davis scrupulously avoided waste and its accompanying nuisances of smoke, noxious fumes and river pollution.

His wide industrial experience brought home to Davis the fact that many promising laboratory processes failed to come to industrial fruition, not because of any chemical defects, but solely owing to the lack of men possessing the skill and knowledge necessary for the erection of adequate plant. The lack of such persons "possessing a knowledge of chemistry, physics and mechanics and who employed their knowledge for the utilization of chemical reactions on the large scale" he strove to set right by delivering, in 1887, a course of lectures on chemical engineering (the first lectures in the world on the subject) at the old Manchester Technical School, now the Manchester College of Technology ; he collected these lectures together, in an expanded form, in his two-volume "Handbook of ChemicaI Engineering", which was published in Manchester in 1901 and was the first text-book on this subject. The seed which Davis sowed in 1887 has flourished, and the vital importance of chemical engineering is now universally recognized.

Mr. Norman Swindin's excellent Memorial Lecture will be published by the Institution of Chemical Engineers and should, and no doubt will, be read by every chemical engineer and student of chemical engineering. Something more than this, however, seems necessary as a memorial to a man who, it is increasingly being realized, was one of the true pioneers of the modern world. In his lecture $\mathrm{Mr}$. Swindin said that Davis strongly advocated the foundation of chairs of chemical engineering and held that the Manchester College of Technology was the ideal training-ground for industrial chemists of all kinds ; the College, for its part, has always insisted on adequate engineering training for all its chemical students and was the first in England to institute a bachelor's degree in chemical engineering. Chemical industry throughout the world owes much to Davis ; it could find no better way of recognizing, and in part repaying, this debt than by adequately endowing, as a memorial to him, the school of chemical engineering in the institution in which he founded the subject and which he admired so much.

H. N. RYDoN 